\title{
A Narrative Study of South African Community Members' Experiences With an International Service-Learning Program
}

Jeremy R. Doughty

University Studies Abroad Consortium, United Kingdom

\section{Recommended Citation}




\title{
A Narrative Study of South African Community Members' Experiences With an International Service-Learning Program
}

\author{
Jeremy R. Doughty \\ University Studies Abroad Consortium, United Kingdom
}

\begin{abstract}
At a time when higher education institutions in the United States are emphasizing global citizenship, more universities are designing and delivering international service-learning (ISL) programs. With the growth of ISL, critical questions must be raised about how these programs affect communities. Despite the centrality of reciprocity in the service-learning paradigm, the extant literature focuses primarily on the effect of ISL programs on students. The purpose of this narrative study was to explore how the stories of members of a South African community-based organization aligned with the principles of democratically engaged ISL programs. The author spent two weeks collecting data at a primary school in a predominantly Black African, Xhosa-speaking township in the Western Cape province of South Africa. The findings concentrate on the cultural meaning that participants gave to the U.S. students' behavior and highlight areas for improvement within the ISL program. A number of practical recommendations for higher education professionals are presented.
\end{abstract}

Keywords: community engagement, international service-learning, narrative inquiry, reciprocity, South Africa, study abroad

\section{Investigación narrativa acerca de las experiencias de miembros de una comunidad sudafricana en}

un programa internacional de aprendizaje en servicio

En un momento en el que las instituciones de educación superior de los Estados Unidos están haciendo cada vez más hincapié en la ciudadanía global, muchas universidades están diseñando y ofreciendo programas internacionales de aprendizaje en servicio (ISL en inglés). Con el crecimiento del ISL, debemos comenzar a plantearnos preguntas esenciales acerca de cómo estos programas afectan a las comunidades involucradas. A pesar de que el concepto de reciprocidad es la base del paradigma del Aprendizaje en Servicio, la literatura existente se centra principalmente en el efecto que tienen estos programas en los estudiantes. El propósito de este estudio fue indagar cómo las experiencias de los miembros de una organización comunitaria sudafricana se alineaban con los principios de los programas de ISL implementados. Pasé dos semanas recopilando datos en una escuela primaria predominantemente de raza negra y de habla xhosa, en un municipio de la provincia del Cabo Occidental de Sudáfrica. Los hallazgos se concentran en el significado cultural que los participantes le dieron al comportamiento de los estudiantes de EE.UU., destacando las áreas a mejorar dentro del programa ISL. También se presentan varias recomendaciones prácticas a tener en cuenta por los profesionales de la educación superior.

Palabras clave: participación comunitaria, programa internacional de aprendizaje en servicio, investigación narrativa, reciprocidad, Sudáfrica, estudios en el extranjero

Editors' Note: Translation by Yamilet Hernandez Department of English and Foreign Languages Barry University, USA

When exploring the websites, promotional brochures, and social media accounts of U.S. universities, one quickly notes higher education's commitment to global citizenship. A university would be remiss if it failed to graduate students equipped to succeed in an increasingly diverse and interdependent society. Organizations such as the Association of American Colleges and Universities (see AAC\&U, 2015) and 
the American Council on Education (see ACE, n.d.) even provide frameworks for supporting the development of global learning.

One approach that universities employ to produce globally oriented graduates is to offer ISL programs. Many researchers have explored the effects of service-learning on students (e.g., Astin et al., 2000; Celio et al., 2011; Eyler \& Giles, 1999; Myers-Lipton, 1998; Warchal \& Ruiz, 2004; Warren, 2012). However, as more U.S. students participate in ISL programs, institutions must avoid the risk of focusing solely on student outcomes and ensure that a collaborative and equal partnership exists between the campus and the community.

Despite the centrality of reciprocity in the service-learning paradigm (Baker-Boosamra, 2006; Camacho, 2004; Dorado \& Giles, 2004; Dostilio et al., 2012; Jacoby, 2015; Le Grange, 2007), several researchers have noted that the current literature has failed to examine the host community's perspective on service-learning experiences (e.g., Bloomgarden, 2017; Blouin \& Perry, 2009; Chapa-Cortés, 2019; Crabtree, 2013; d'Arlach et al., 2009; Miron \& Moely, 2006; Mogford \& Lyons, 2019; Schroeder et al., 2009; Tryon et al., 2008). In order to understand whether ISL programs are genuinely just, fair, and inclusive, more researchers must explore host community perspectives. Research on the effects of ISL programs on community members is "woefully thin" (Bloomgarden, 2017, p. 21), "lagging" (Crabtree, 2013, p. 60), and "rare" (d'Arlach et al., 2009, p. 6), and as Santiago-Ortiz (2019) noted recently, most service-learning literature focuses on the college student performing the service, not the long-term community impact.

The purpose of my study was to shift the conversation from the university and its students to the community. I explored how the stories of members of a community-based organization aligned with the principles of democratically engaged ISL programs. More specifically, I focused on the lived experiences of South Africans who had engaged with U.S. postsecondary students participating in a semester-long ISL program.

\section{International Service-Learning}

One of the fastest growing movements in service-learning (Jacoby, 2015), ISL diversifies an institution's internationalization and civic engagement efforts. Participation in ISL enhances students' intercultural competence (Brown, 2011; Crabtree, 2008; Kiely, 2004; Prins \& Webster, 2010), strengthens their leadership skills (Brown, 2011; Crabtree, 2008), increases their understanding of complex global problems related to their academic discipline (Kiely, 2004), and heightens their sense of social responsibility and civic engagement (Brown, 2011; Crabtree, 2008; Tonkin \& Quiroga, 2004). However, Deeley (2010) cautioned that there is no guarantee that these benefits will materialize, especially since ISL programs do not share the same pedagogy and practice (Santiago-Ortiz, 2019). Moreover, the unpredictability of ISL may result in challenges for the host community.

\section{Critiques of ISL Programs}

International service-learning programs are complex endeavors that take a considerable amount of time and thought to design, and ISL courses do not always achieve their desired reciprocal relationships. In fact, Crabtree (2013), McMillan and Stanton (2014), and Sharpe and Dear (2013) warned that the outcomes of ISL may be the opposite of what community members, faculty, and students anticipate. Jones (2002a) noted that service-learning experiences may reinforce negative stereotypes and assumptions. Thomas and Chandrasekera (2013) added that international service placements "often reinforce and reproduce ... historical hegemonic power dynamics" (p. 91), and Hartman et al. (2014) along with MacDonald (2013) asserted that there are ways service work abroad resembles new forms of colonialism.

Tiessen and Huish (2013) questioned whether international experiential learning programs produce globetrotters or global citizens. Critics such as Reilly and Senders (2009), Tiessen (2013), and ZemachBersin (2007) have argued that these programs produce globetrotters who view the world as an opportunity for individual enrichment. Reilly and Senders (2009) posited that some ISL participants 
exploit cultural acquisition to increase their own social and cultural capital. In a similar tone, Tiessen (2013) drew attention to the ethical implications associated with ISL programs that are characterized by students' travel from the Global North to the Global South to gain practical experience in their field of study. Zemach-Bersin (2007) also criticized U.S. students for mimicking the dynamics of imperialism and colonialism, noting that U.S. students who identify as global citizens "[assume] the right to travel unhindered, to penetrate cultures without the hassle of boundaries, to extend [their] rights of citizenship transnationally, and to unabashedly profit from this imperialist global arrangement" (p. 22).

When an ISL program is not firmly grounded in the fundamental principles of shared power and mutual respect, the community becomes "a laboratory for the use of privileged students" (BakerBoosamra, 2006, p. 8) or "small theaters that recreate historic cultural misunderstandings and simplistic stereotypes" (Grusky, 2000, p. 858). Although service-learning is heralded for its focus on social justice, critics (e.g., Santiago-Ortiz, 2019) have argued that service-learning may actually reinforce power differentials. Stanlick and Sell (2017) even suggested that faculty, staff, and students may develop a superhero complex when collective empowerment is not prioritized, with community partners being relegated to the role of sidekick or recipient when university groups arrive in their host community.

\section{Conceptual Framework}

To maintain a focus on the community throughout my study, I relied on Saltmarsh et al.'s (2009) notions of technocratic engagement and democratic engagement, or, as Jameson et al. (2011) posited, thin reciprocity and thick reciprocity. This conceptual framework is relevant in light of Stanlick and Sell's (2017) argument that "we are just scratching the surface of understanding the difference between technocratic and democratic partnerships" (p. 80). Relationships characterized by technocratic engagement favor academic-based over community-based knowledge (Saltmarsh et al., 2009). Since this approach privileges a university's expertise, deficit-based projects are often designed by universities, and "engagement is enacted for the public" (Saltmarsh et al., 2009, p. 8). Jameson et al. (2011) referred to this type of minimalist, asymmetrical engagement as thin reciprocity since the relationship is not always equal or sustainable, questions of power are often ignored, and outcomes typically favor students.

Conversely, democratic engagement refers to the equitable contribution of faculty members, practitioners, students, and community members throughout the service-learning life cycle (Saltmarsh et al., 2009). This asset-based, non-hierarchical approach is characterized by the multidirectional flow of knowledge. Stakeholders from the university and the community contribute their expertise and share their experiences as co-educators. By employing a deep, or thick, understanding of reciprocity that emphasizes

shared voice and joint ownership of projects (Jameson et al., 2011), universities engage "with the public and not merely for the public" (Saltmarsh et al., 2009, p. 9).

\section{Methods}

The following research question guided my narrative study: How do the stories of members of a South African community-based organization align with the principles of democratically engaged ISL programs? I focused on the lived experiences of community members at Korhaan School, a servicelearning site for South Point University's (SPU) and St. Dominic University's (SDU) semester-long ISL program in South Africa. To mask the identity of the participants, I selected pseudonyms for the two universities (i.e., SPU and SDU), the primary school (i.e., Korhaan School), and the community where the primary school is situated (i.e., Ithemba). I also used the names selected by participants.

\section{Narrative Inquiry}

Narrative inquiry begins with individuals' lived experiences, the stories about these experiences and how the individuals make meaning of them, and the social situations in which the experiences take place (Creswell, 2013; Jones et al., 2014; Josselson \& Lieblich, 2003). A distinguishing feature of this method is the three-dimensional narrative-inquiry space approach, which concentrates on sociality, continuity, 
and situation (Clandinin, 2006; Jones et al., 2014; Ollerenshaw \& Creswell, 2002). Sociality refers to the integral relationship between an individual and the social context. Continuity denotes the interconnectedness of experiences that are situated in the past, present, and future. Situation comprises the environments where the inquiry and the experiences take place. Since narratives have "a robust life beyond the individual" (Riessman, 2008, p. 7), the three-dimensional approach pushed me to explore the sociocultural, political, historical, and educational narratives within which the study participants' experiences were shaped. The three-dimensional approach helped me, as a researcher, maintain focus on and illuminate a gap in the literature: the stories of community members.

\section{Site Selection}

I was introduced to SPU, a public university in South Africa's Western Cape province, during a twomonth internship experience. I learned about SPU's semester-long ISL program with SDU, a private university in the midwestern United States with roughly 12,000 undergraduate and graduate students. Each semester, the U.S. undergraduates who participate in the ISL program take classes at SPU two days per week, serve at a community-based organization two days per week, and participate in two SDU courses one day per week. Korhaan School, a primary school in the predominantly Black African, Xhosaspeaking township of Ithemba, is one of the community-based organizations where the students serve.

\section{Participants}

Since the intent of narrative inquiry is to elucidate the particular, my study included three participants at Korhaan School: Bhejile (the principal), Dunyiswa (the deputy principal), and Peline (a teacher who had collaborated with U.S. undergraduates). These three individuals had the highest degree of involvement with the ISL program at Korhaan School. Jones (2002b) acknowledged that more attention should be devoted to achieving a deeper understanding of the research problem than to the number of participants. Morrow (2005) agreed, arguing that "insights generated from qualitative inquiry have more to do with information-rich cases than with sample size" (p. 255).

Bhejile. The principal, Bhejile, was a Xhosa-speaking Black African like most of his colleagues and the learners at the primary school. Often dressed in embroidered garments in earth-tone colors, Bhejile spoke with tranquility and wisdom. During a tour of the school, the young learners in their navy, light blue, and grey uniforms displayed their affection for Bhejile by waving, flashing a thumbs-up, holding his hand for a short stroll, or embracing him with a quick hug.

Originally from the Eastern Cape province, Bhejile considered Ithemba his "home away from home." Prior to his arrival at Korhaan School, Bhejile taught at the secondary level. At the time of this study, he oversaw an entire primary school:

My job is to make sure that teaching is taking place at the school. Learners know when to be in class and to go out of class. Make sure that educators regularly come to school prepared. . . And the reporting to the [Department of Basic Education] about what is happening in the school. Accessing resources from the [department]. Making sure that educators get necessary resources. Reporting to parents about the progress and the challenges that [we] now are facing ... in the school. Trying to involve them so as to work as a team because, in education, if we want to get into the learners, we must involve all parties.

Dunyiswa. Bhejile was assisted by Dunyiswa, the deputy principal at Korhaan School. Similar to Bhejile, Dunyiswa was a Xhosa-speaking Black African from the Eastern Cape province. Dunyiswa, who radiated positivity with her wide smile and engaging personality, was deeply committed to the learners at the primary school. She explained that "our learners are our first priority." Dunyiswa illustrated her commitment to the learners by detailing the risks she was willing to take:

For example, if a learner is sick, and I take my car, I bring that learner home, something happens to me there, the Department [of Basic Education] will not even pay me. They will tell me, "You 
were at the wrong place." And, they will not even bother themselves that my reason why I was there. ... They will not say, "You sort of caring, you were looking after this learner, you wanted to protect this learner, you were looking of the safety of this learner." ... So, they only saying, "You were at the wrong place. Your place is at the school, not outside the school."

Dunyiswa offered the same dedication to the U.S. students who served at the school as part of the ISL program. Bhejile stated that his role with the U.S. students was to "welcome them" and to "make sure that they feel at home," and Dunyiswa "makes sure that whatever they need" they had.

Peline. Dunyiswa was responsible for placing the U.S. students with teachers like Peline, a mathematics (maths) teacher who had worked at Korhaan School since 2012. Since Bhejile and Dunyiswa identified maths as a curricular area needing attention, and given the subject's importance in the Department of Basic Education's national testing scheme, Peline had collaborated with U.S. students to teach maths to learners in Grades 6 through 9.

Peline, a Xhosa-speaking Black African, initially presented as shy but slowly opened up during my two weeks at Korhaan School. Reminiscing about her past experiences with the U.S. students, Peline described the characteristics she appreciated: "Someone who's friendly. Someone who can be, who can act as a parent to kids because they need that parent material. A person who is really willing to teach, who's willing to share knowledge with kids."

\section{Data Collection}

A researcher conducting narrative inquiry needs to select participants who have stories to tell and then spend considerable time with those participants, gathering their stories through multiple methods (Creswell, 2013). García and Longo (2017) celebrated storytelling as a tool in the context of ISL programs, noting that stories help individuals understand the complexities of life. The methods that I used-interviews and a focus group-provided me with the data I needed to answer my research question.

Interviews. I conducted two interviews with each of the three participants. The interviews followed a semi-structured protocol and were recorded digitally. The interviews took place at Korhaan School in a space where the participants felt comfortable. My first interviews with Bhejile (70 minutes) and Dunyiswa (55 minutes) were longer than my initial interview with Peline (35 minutes) due to Peline's limited availability. Using the three-dimensional narrative-inquiry space approach to guide my first interviews, I asked questions that concentrated on interactions between former and current U.S. undergraduates assigned to Korhaan School and the study participants (sociality); the past, present, and future of the ISL program (continuity); and Korhaan School and Ithemba (situation).

During my second interview, I focused on member checking, confirming the accuracy of facts and my interpretation of my participants' stories from the first interview. I also asked questions that deepened my understanding of the participants' experiences with the ISL program. Again, my interviews with Bhejile ( 80 minutes) and Dunyiswa (65 minutes) were longer than my interview with Peline (25 minutes) due to the limited breaks between Peline's lessons.

Focus group. Kamberelis and Dimitriadis (2011) described focus groups as "collective conversations or group interviews" (p. 545). The socially oriented nature of a focus group has the potential to stimulate reflections that may not be captured in individual interviews (Kvale \& Brinkman, 2009) and provide a researcher with richer, thicker, and more complex levels of understanding (Kamberelis \& Dimitriadis, 2011). Onwuegbuzie et al. (2009) added that focus groups may be less threatening to participants than individual interviews.

Following my second interview with Bhejile and my first interview with Dunyiswa, I conducted a 65minute focus group with the principal and the deputy principal. Peline was scheduled to attend, but Bhejile informed me before the start of the focus group that she was no longer able to participate. It remains unclear if power differentials (e.g., administrator-teacher, researcher-teacher) played a role in Peline's absence. I asked Bhejile and Dunyiswa questions about cultural frameworks of service, characteristics of effective ISL programs, and areas for improvement within their ISL program. 


\section{Data Analysis}

The aim of the narrative analysis was to gain an overall sense of the meaning the participants made of their lived experiences. I began organizing my data during the data collection process in South Africa, and I continued organizing the data upon my return to the United States. After I transcribed the interviews and the recording from the focus group, I immersed myself in the transcripts.

Coding the data was the next step in the data analysis process. I began with open coding, or coding line by line. Saldaña (2013) explained that a code is "most often a word or short phrase that symbolically assigns a summative, salient, essence-capturing, and/or evocative attribute for a portion of language-based or visual data" (p. 3). I then progressed to axial coding and collapsed the open codes into themes related to one another.

I articulated the lessons I learned and detailed the larger meaning behind the participants' lived experiences. I determined what was story-worthy and then relied on the three-dimensional narrativeinquiry space approach and my conceptual framework for restorying, which Creswell (2013) defined as a "process of reorganizing the stories into some general type of framework" (p. 74). In addition to focusing on sociality, continuity, and situation, I also considered the characteristics of technocratic engagement (thin reciprocity) and democratic engagement (thick reciprocity) in my analysis.

\section{Findings}

In the following restory, I first introduce $u b u n t u$, the cultural meaning that my participants gave to the U.S. students' behavior, and then describe areas for improvement of the ISL program. Throughout the restory, I emphasize the voices of Bhejile, Dunyiswa, and Peline - a hallmark of narrative inquiry (Creswell, 2013) intended to illuminate the human experience (Jones et al., 2014).

\section{Ubuntu}

Bhejile, Dunyiswa, and Peline shared several stories that captured the ISL program's positive effects on Korhaan School. The U.S. students (1) increased the motivation of the learners as evidenced by the learners' more fluid use of English; (2) established strong relationships with the Korhaan School community that served as catalysts for meaningful interpersonal interactions; (3) introduced new perspectives to the administrators, teachers, and learners; (4) provided curricular support; (5) and engaged in insightful cross-cultural exchanges.

Despite these benefits, I anticipated that there would be a disconnect between Western and Africanized notions of service. I was mistaken. Bhejile, Dunyiswa, and Peline introduced me to ubuntu, a cultural framework that shaped their understanding of service and their engagement with others. The essence of ubuntu is helping someone who is in need, and it results in an ongoing cycle of selfless service and kindness aimed at bettering the whole community. Bhejile remarked, "If someone is in trouble or is in a need of something and you have, and you are able to help, we refer that as ubuntu. Because we've got that, it's our own way of doing things." Similarly, Dunyiswa noted, "It's about helping the people. It's about the needs that they have. You are able to help them with the needs that they do." Peline's description paralleled Bhejile's and Dunyiswa's: "It means to me being able to help others when they need you the most. To be friendly to people. And the career I chose, being a teacher, you must associate yourself with ubuntu."

During the focus group, Bhejile and Dunyiswa co-constructed an example that illustrated ubuntu in the context of Korhaan School. In the winter months, some homes in Ithemba catch fire. The homes are often constructed from reclaimed materials such as metal and wood. Families use makeshift methods to heat their homes, which can be dangerous. Bhejile cited a recent example: 
Presently, a child, we were told by a teacher that their home, a shack where she stays with her mother, everything got on fire. And then, they only have what they have is on them, you know. Now, the teacher told us about this. ... The following day, teachers, certain teachers come, because they've got clothes of that, came with clothes, so that they can be given to that family.

Bhejile, Dunyiswa, and Peline explained that ubuntu was within them; it was part of their cultural identity. I was curious to learn if U.S. students who understood service from a Western perspective could exhibit behaviors that aligned with this Africanized framework. "Yes, I mean, they display that in many ways," answered Bhejile. "They believe in the culture of ubuntu," responded Dunyiswa. Peline also agreed: "Yes, of course, of course."

Bhejile, Dunyiswa, and Peline shared stories that illustrated how the U.S. students' attitudes and behaviors reflected ubuntu. The U.S. students were particularly skilled at identifying and supporting learners who faced significant social challenges. Peline stated that the U.S. students had "a good eye in identifying learners who have a problem, like at home." Dunyiswa recalled the behavior of one U.S. student:

What I liked, she would pick up those who are very poor, who have nothing like shoes, the uniform, all those things. She was easy to see the types of learners who are very much struggling. And she would come to me and ask, "What can we do just to help the learner?" ... Then, it spread. If she's not in that class, she was able to see in another class.

Bhejile agreed with Dunyiswa and Peline that the U.S. students "display to us what is original ubuntu behavior." In fact, he clarified that individuals did not need to come from a particular racial or ethnic background, geographic location, or culture to understand ubuntu:

It doesn't necessarily mean that you have to be coming from this culture of ours. Your action will say that person is having ubuntu. Because your action may qualify you ... as a person who's got ubuntu irrespective of which culture you're coming from.

\section{Areas for Improvement Within the ISL Program}

Although the U.S. students exhibited ubuntu behavior, two major areas for improvement within the ISL program surfaced in the stories that Bhejile, Dunyiswa, and Peline shared. First, the participants were unclear about the purpose of the program. Second, the principal, deputy principal, and teacher expressed a desire for a higher degree of engagement in the life cycle of the ISL program, especially regarding reflection sessions with the program director and the U.S. students.

Unclear purpose of the program. One of the most fundamental components of the ISL programthe purpose - remained unclear to Bhejile, Dunyiswa, and Peline. Bhejile, who wondered if the U.S. students served at Korhaan School as a way to fill empty time in their schedules, explained that "we don't know the purpose of this exchange." He spoke with concern:

I don't know ... what they want to achieve. I always don't know whether they just give us these exchange students because they are there. Probably they've got nothing to do. Do they have a certain vision or something they want to get out of taking these [students] outside?

Dunyiswa echoed Bhejile's remarks:

So, I will say that's where we think that it can change. Just to know what's the purpose. For example, by the end of this, what is it that you want to achieve? What is it that, as a school, we want you to achieve? So that we work towards that. So that we improve.

Along with the lack of clarity about the purpose of the ISL program, the learning outcomes for the U.S. students and the expected outcomes for Korhaan School were unknown. If Bhejile and Dunyiswa were unable to assess the outcomes for the U.S. students and the school, how could they ensure the effectiveness of the ISL program and remain committed to future growth? Dunyiswa voiced her concerns: 
No, it's like the purpose of the program, it does not give us, in terms of measuring the output. For example, what is the part they want to achieve with the program? Then we don't know where we are. But, if we have something that we can use to measure where we are, then we'd know where to improve. Because the students will come next year, new students will come, they will not know, even with the previous one, we don't know whether they achieved what the purpose was for.

Since the academic calendars of SPU and SDU are divided into two semesters, new U.S. students arrive at and depart Korhaan School twice per year. For each group of students, Bhejile recommended that "there should be some involvement of some information" about the purpose of the program and what the U.S. students aim to achieve. Dunyiswa's suggestion paralleled Bhejile's. She desired more information about "the background of the program" and an answer to the question, "What is it that they want to achieve?"

Lack of involvement in reflection. Considering the centrality of reflection and reciprocity in the service-learning paradigm, I asked my participants about the extent to which they were involved in reflection with the director of the ISL program and the U.S. students. Bhejile reported that "there's never been an opportunity where we debated this; we shared our views about these processes." He asserted that "there are supposed to be certain meetings where we reflect," but "it's not there, it's not there."

By facilitating more reflection sessions with the Korhaan School community, SPU, SDU, and Korhaan School could, Bhejile argued, "together shape the program." Bhejile called for a meeting between the director of the ISL program and representatives of the schools where the U.S. students served:

Just to organize a meeting of principals or whoever in the schools are involved with this so that to check our expectations, to check for us, to check what the purpose of this exercise from their side. To us, when you see these [students], we know where to use them.

Similarly, Dunyiswa underscored the need for a higher degree of engagement between the director of the ISL program, the administrators at the Korhaan School, and the teachers at the primary school. She also advocated more reflection with the U.S. students:

They come and go, they come and go, they come and go. ... We never heard any information from [the students] how the program changed, how the school changed their lives. What is it that they've gained after visiting the school?

\section{Discussion}

The stories about the U.S. students' ubuntu behavior highlight the positive effects of the ISL program. However, the participants' stories about the unclear purpose of the program and their lack of involvement in reflection signaled that the ISL program is defined primarily by the principles of technocratic engagement (thin reciprocity) rather than democratic engagement (thick reciprocity). Bhejile, Dunyiswa, and Peline lacked a sense ownership, and their voices did not inform the design and delivery of the program. Moreover, the asymmetrical power dynamics and minimalist engagement of the community partners at Korhaan School threaten the long-term sustainability of the partnership. These findings align with van Rensburg's (2014) argument that service-learning partnerships between universities and community-based organizations are frequently characterized by thin reciprocity.

Bhejile, Dunyiswa, and Peline expressed a desire to be engaged in the life cycle of the ISL program. Education is a social process, and everyone involved in that process has something to contribute (Dewey, 1938). By excluding community members, U.S. institutions forego expert knowledge and, consequently, deliver programs that align with the characteristics of technocratic engagement. When designing new ISL programs, higher education professionals should consider the steps described below in an effort to build democratically engaged partnerships. 


\section{Build the Foundation}

If a U.S. university determines that a new ISL program aligns with its strategic plan and furthers its mission, higher education professionals should proceed slowly and thoughtfully with program design. A university should allocate time (i.e., at least one year) and funds to support the design of an ISL program that is defined by thick reciprocity. Faculty members and practitioners should begin by building a foundation for a possible collaboration with the host community - a step that was overlooked at Korhaan School. Bhejile stated that "we don't know the purpose of this exchange," and he expressed a desire to "together shape the program" with the U.S. and South African universities. Dunyiswa added, "That's where we think that it can change. Just to know what's the purpose."

Considering the centrality and complexity of culture in developing academic programs that cross borders, higher education professionals and host community representatives should conduct site visits to learn more about the organizations involved in the partnership and to examine the vision, goals, and outcomes of the ISL program. The fair-trade learning construct, developed by the Association of Clubs in Jamaica, in collaboration with Amizade Global Service Learning in the United States (Hartman et al., 2014), serves as a helpful framework for developing democratically engaged partnerships. In particular, Hartman (2015) raised practical questions that serve as a helpful point of departure for stakeholders (e.g., Do stakeholders agree on long-term mutuality of goals and aspirations? Do all stakeholders understand the nature of partnership commitments? Is the economic impact of the partnership deliberately distributed among multiple stakeholders?).

Similarly, Bennett (2018) introduced a straightforward framework for organizing relationship-based reciprocity in service-learning experiences. Bennett's framework includes practical questions related to relationships, objectives, structure, and outcomes for instructors, community partners, and students, with the aim of creating democratically engaged partnerships. Additionally, NAFSA: Association of International Educators (https://www.nafsa.org) provides site-visit checklists and evaluations, and the Forum on Education Abroad (https://forumea.org) maintains standards of good practice for education abroad and guidelines for community engagement, service-learning, and volunteer experiences abroad.

\section{Build Relationships and Mutual Respect}

Attention must be devoted to building relationships and mutual respect (Schaffer et al., 2015; Schroeder et al., 2009). To establish partnerships defined by democratic engagement, higher education professionals need to be systematic about including broad community perspectives (Hartman et al., 2014). Bhejile drew attention to the missed opportunity to build relationships, commenting that "there are supposed to be certain meetings where we reflect," but "it's not there, it's not there." Shallenberger (2015), who explored the major career takeaways of international educators, reminded faculty members and practitioners to balance the piles of papers, endless emails, back-to-back meetings, and unanswered voicemails with relationship building.

One way to build relationships and mutual respect is by learning about and incorporating the cultural frameworks of the host community. Service-learning is dominated by North American theory and practice (Brown, 2011). Faculty members, practitioners, and students from the U.S. United States must be mindful that Western concepts and models may not always align with the contexts of the host community. In her recent study of an ISL program in Yucatán, México, Chapa-Cortés (2019) examined the cultural and social factors that influence how host communities contribute to and learn from ISL experiences.

For example, the stories of Bhejile, Dunyiswa, and Peline highlighted the centrality of ubuntu in South African communities. Since the U.S. students were not the focus of my research, the extent to which they understood ubuntu and were intentional in their behavior as a form of conceptual reciprocity remains unclear. Yet, considering the prominence of the cultural framework, it is imperative that higher education professionals and students at SDU have a rich understanding of ubuntu. 
A second way to build relationships and mutual respect is by expanding the network of stakeholders. In the same way that universities should avoid designing one-off ISL courses, faculty members and practitioners should avoid designing narrowly focused programs that exacerbate the silos that exist on some campuses. In the spirit of long-term sustainability, higher education professionals should explore additional experiences with the same community-based organization abroad that complement the ISL program and promote mobility in both directions: alternative break programs, short-term and semesterlong student mobility programs, collaborative research and visiting scholar opportunities, leadership and professional development programs, classroom integration, center/institute initiatives (e.g., collaboration with a center for economic development), and engagement with local community-based organizations in the United States.

\section{Build the ISL Program}

After the U.S. institution and the host community define the parameters of a sustainable and mutually beneficial partnership, the details should be captured in a memorandum of understanding (MoU). The MoU should make clear that community members are "co-educators, co-learners, and co-generators of knowledge" (Jameson et al., 2011, p. 260), a hallmark of democratically engaged partnerships. Bringle and Hatcher (2011) and Whitney et al. (2016) concurred that community members must assume a leadership role, especially since they have expert knowledge of the history, sociocultural context, needs, and resources of their communities (Hicks et al., 2015). Similarly, de Beer (2014) advocated celebrating knowledge production as a two-way process. These ideas align clearly with the key characteristics of relationships that are defined by thick reciprocity: shared voice, joint ownership, and the multidirectional flow of knowledge.

With a solid foundation built, key stakeholders at the U.S. institution and in the host community should co-design the course, starting with the identification of learning outcomes and a plan for measuring these outcomes. At Korhaan School, Bhejile asserted, "I don't know... what [the U.S. students] want to achieve." Dunyiswa, echoing Bhejile's remarks, questioned, "By the end of this, what is it that [the U.S. students] want to achieve?" Dunyiswa suggested that mutually developed learning outcomes will strengthen the relationship between the U.S. students and community members and result in more effective outcomes at Korhaan School.

There are several resources for aiding faculty members in the design of a democratically engaged ISL course. GlobalSL (https://compact.org/global-sl), a collaborative effort hosted by Haverford College, uses fair-trade learning as a framework for promoting ethical global learning. In addition to a helpful fair-trade learning rubric, faculty members can access model syllabi; resources on learning outcomes; activities on border crossing, power, privilege, and reflection; and recent research on ISL programs.

\section{Limitations}

As is the case for all research, there were limitations that undoubtedly affected this study. First, during my initial visit to Korhaan School, I learned that, due to the school's daily timetable, Peline was only available only during a 30-minute period in the morning between classes. Additionally, Peline was scheduled to participate in a portion of the focus group, but she did not attend. Second, though English was the language that the study participants and I spoke in common, it was a second (or third or fourth) language for Bhejile, Dunyiswa, and Peline. Considering the interconnectedness of language and culture, stories were likely lost in translation and during narration. Third, I provide minimal details about the structure of SPU's and SDU's ISL programs, which Eyler and Giles (1999) characterized as "a consistently important factor in the effectiveness of service-learning" (p. 32). Although I acknowledge the relevance of the structure of ISL programs, the stories of my participants did not concentrate on the logistical components associated with the partnership between SPU, SDU, and Korhaan School. 


\section{Suggestions for Future Research}

Let us consider some suggestions for future research. First, more stakeholders should be integrated into future research. In this study, I found that Bhejile, Dunyiswa, and Peline were unfamiliar with the purpose of the ISL program. Researchers could examine how various stakeholders involved in the program (e.g., higher education professionals at the home and host universities, the U.S. students, individuals at the community-based organization, the onsite program director, local families in the host community) understand the program's purpose. Involving more community members underscores the relevance of local knowledge and has the potential to empower more stakeholders.

Second, researchers should get closer to and diversify community voices. My study concentrated on one community-based organization in one township in one country. Researchers must amplify the voices of community members in different cultural and community contexts. Furthermore, as ISL programs continue to grow, researchers must engage community members not only as participants but also as coinvestigators.

Third, future research should explore the effects of different program models on community members. SPU and SDU deliver a semester-long ISL program. Additional models include programs organized by third-party providers in which the home university collaborates with a private company; short-term, faculty-led programs in which faculty members design and deliver a program of eight weeks or less; non-credit "voluntourism" and alternative break programs; and year-long programs.

\section{Conclusion}

With the growth of ISL, more questions must address how these programs affect communities. Sharpe and Dear (2013) noted that the increase in the number of U.S. postsecondary students who participate in these programs has raised some "troubling concerns, many of which relate to the ways that the actual, onthe-ground activities seem to challenge or contradict the intended and purported aims of ISL" (p. 49). Earlier, Blouin and Perry (2009) observed that "research on the community impacts [of ISL] remains sparse and limited," and the voices of community members were "largely absent in the service-learning literature" (p. 122).

The study participants' stories highlighted some of the benefits and challenges associated with ISL programs. I hope that the voices of Bhejile, Dunyiswa, and Peline inspire higher education professionals to examine critically the policies and practices associated with ISL programs and broader internationalization efforts. I challenge faculty members and practitioners to think and operate in new ways that foreground the underserved and that empower communities. As we reflect on the power and privilege associated with international programs, let us discover new approaches that amplify the voices of the marginalized. Let us construct more meaningful partnerships characterized by thick reciprocitypartnerships that are more inclusive, just, and reciprocal.

\section{References}

American Council on Education. (n.d.). Internationalization toolkit. https://www.acenet.edu/ResearchInsights/Pages/Internationalization/Internationalization-Toolkit.aspx

Association of American Colleges and Universities. (2015). Global learning VALUE rubric. https://www.aacu.org/value/rubrics/global-learning

Astin, A. H., Vogelgesang, L. J., Ikeda, E. K., \& Yee, J. A. (2000). How service-learning affects students. Higher Education Research Institute, University of California, Los Angeles.

Baker-Boosamra, M. (2006). From service to solidarity: Evaluation and recommendations for international service learning. SPNA Review, 2(1), 1-21. https://scholarworks.gvsu.edu/spnareview/vol2/iss1/2/

Bennett, E. (2018). A simple, practical framework for organizing relationship-based reciprocity in service-learning experiences: Insights from anthropology. International Journal of Research on 
Service-Learning and Community Engagement, 6(1), Article 2. https://ijrslce.scholasticahq.com/article/6999

Bloomgarden, A. H. (2017). Out of the armchair: About community impact. International Journal of Research on Service-Learning and Community Engagement, 5(1), 21-23. https://journals.sfu.ca/iarslce/index.php/journal/article/view/307

Blouin, D. D., \& Perry, E. M. (2009). Whom does service learning really serve? Community-based organizations' perspectives on service learning. Teaching Sociology, 37(2), 120-135. https://www.jstor.org/stable/25593983

Bringle, R. G., \& Hatcher, J. A. (2011). International service learning. In R. G. Bringle, J. A. Hatcher, \& S. G. Jones (Eds.), International service learning: Conceptual frameworks and research (pp. 3-28). Stylus.

Brown, N. C. (2011). A 360-degree view of international service learning. In R. G. Bringle, J. A. Hatcher, \& S. G. Jones (Eds.), International service learning: Conceptual frameworks and research (pp. 5785). Stylus.

Camacho, M. M. (2004). Power and privilege: Community service learning in Tijuana. Michigan Journal of Community Service Learning, 10(3), 31-42. http://hdl.handle.net/2027/spo.3239521.0010.303

Celio, C. I., Durlak, J., \& Dymnicki, A. (2011). A meta-analysis of the impact of service-learning on students. Journal of Experiential Education, 34(2), 164-181. https://doi.org/10.1177/105382591103400205

Chapa-Cortés, C. (2019). What the community learns: International service-learning in Yucatán, México. International Journal of Research on Service-Learning and Community Engagement, 7(1), Article 12. https://ijrslce.scholasticahq.com/article/11493

Clandinin, D. J. (2006). Narrative inquiry: A methodology for studying lived experience. Research Studies in Music Education, 27(1), 44-54. https://doi.org/10.1177/1321103X060270010301

Crabtree, R. D. (2008). Theoretical foundations for international service-learning. Michigan Journal of Community Service Learning, 15(1), 18-36. http://hdl.handle.net/2027/spo.3239521.0015.102

Crabtree, R. D. (2013). The intended and unintended consequences of international service-learning. Journal of Higher Education Outreach and Engagement, 17(4), 43-66. https://openjournals.libs.uga.edu/jheoe/article/view/1042

Creswell, J. W. (2013). Qualitative inquiry \& research design: Choosing among five approaches (3rd ed.). SAGE.

d'Arlach, L, Sánchez, B., \& Feuer, R. (2009). Voices from the community: A case for reciprocity in service-learning. Michigan Journal of Community Service Learning, 16(1), 5-16. http://hdl.handle.net/2027/spo.3239521.0016.101

de Beer, S. (2014). Reimagining the third sector and its engagement with higher education institutions and local neighbourhoods: From scarcity to sustainability. In M. Erasmus \& R. Albertyn (Eds.), Knowledge as enablement: Engagement between higher education and the third sector (pp.119-144). Sun Press.

Deeley, S. J. (2010). Service-learning: Thinking outside the box. Active Learning in Higher Education, 11(1), 43-53. https://doi.org/10.1177/1469787409355870

Dewey, J. (1938). Experience and education. Macmillan.

Dorado, S., \& Giles, D. E., Jr. (2004). Service-learning partnerships: Paths of engagement. Michigan Journal of Community Service Learning, 11(1), 25-37. http://hdl.handle.net/2027/spo.3239521.0011.103

Dostilio, L. D., Brackmann, S. M., Edwards, K. E., Harrison, B., Kliewer, B. W., \& Clayton, P. H. (2012). Reciprocity: Saying what we mean and meaning what we say. Michigan Journal of Community Service Learning, 19(1), 17-32. http://hdl.handle.net/2027/spo.3239521.0019.102

Eyler, J., \& Giles, D. E., Jr. (1999). Where's the learning in service-learning? Jossey-Bass.

García, N. A., \& Longo, N. V. (2017). Doing more with less: Civic practices for longer-term impact in global service learning. Frontiers: The Interdisciplinary Journal of Study Abroad, 29(2), 35-50. https://doi.org/10.36366/frontiers.v29i2.391 
Grusky, S. (2000). International service learning: A critical guide from an impassioned advocate. American Behavioral Scientist, 43(5), 858-867. https://doi.org/10.1177/00027640021955513

Hartman, E. (2015). A strategy for community-driven service-learning and community engagement: Fair trade learning. Michigan Journal of Community Service Learning, 22(1), 97-100. http://hdl.handle.net/2027/spo.3239521.0022.113

Hartman, E., Paris, C. M., \& Blache-Cohen, B. (2014). Fair trade learning: Ethical standards for international volunteer tourism. Tourism and Hospitality Research, 14(1-2), 108-116. https://doi.org/10.1177/1467358414529443

Hicks, T., Seymour, L., \& Puppo, A. (2015). Democratic relationships in service-learning: Moving beyond traditional faculty, student, and community partner roles. Michigan Journal of Community Service Learning, 22(1), 105-108. http://hdl.handle.net/2027/spo.3239521.0022.115

Jacoby, B. (2015). Service-learning essentials: Questions, answers, and lessons learned. Jossey-Bass.

Jameson, J. K., Clayton, P. H., \& Jaeger, A. J. (2011). Community-engaged scholarship through mutually transformative partnerships. In L. M. Harter, J. Hamel-Lambert, \& J. L. Millesen (Eds.), Participatory partnerships for social action and research (pp. 259-277). Kendall Hunt Publishing.

Jones, S. R. (2002a). In over our heads: The underside of service-learning. About Campus, 7(4), 10-15. https://doi.org/10.1177/108648220200700403

Jones, S. R. (2002b). (Re)writing the word: Methodological strategies and issues in qualitative research. Journal of College Student Development, 43(4), 461-473.

Jones, S. R., Torres, V., \& Arminio, J. (2014). Negotiating the complexities of qualitative research in higher education: Fundamental elements and issues (2nd ed.). Routledge.

Josselson, R., \& Lieblich, A. (2003). A framework for narrative research proposals in psychology. In R. Josselson, A. Lieblich, \& D. P. McAdams (Eds.), Up close and personal: The teaching and learning of narrative research (pp. 259-274). American Psychological Association.

Kamberelis, G., \& Dimitriadis, G. (2011). Focus groups: Contingent articulations of pedagogy, politics, and inquiry. In N. K. Denzin \& Y. S. Lincoln (Eds.), The SAGE handbook of qualitative research (pp. 545-561). SAGE.

Kiely, R. (2004). A chameleon with a complex: Searching for transformation in international servicelearning. Michigan Journal of Community Service Learning, 10(2), 5-20. http://hdl.handle.net/2027/spo.3239521.0010.201

Kvale, S., \& Brinkman, S. (2009). Interviews: Learning the craft of qualitative research interviewing. SAGE.

Le Grange, L. (2007). The "theoretical foundations" of community service-learning: From taproots to rhizomes. Education as Change, 11(3), 3-13. https://doi.org/10.1080/16823200709487174

MacDonald, K. (2013). (De)colonizing pedagogies: An exploration of learning with students volunteering abroad. In R. Tiessen \& R. Huish (Eds.), Globetrotting or global citizenship? Perils and potential of international experiential learning (pp. 209-229). University of Toronto Press.

McMillan, J., \& Stanton, T. K. (2014). "Learning service" in international contexts: Partnership-based service-learning and research in Cape Town, South Africa. Michigan Journal of Community Service Learning, 21(1), 64-78. http://hdl.handle.net/2027/spo.3239521.0021.106

Miron, D., \& Moely, B. E. (2006). Community agency voice and benefit in service-learning. Michigan Journal of Community Service Learning, 12(2), 27-37. http://hdl.handle.net/2027/spo.3239521.0012.203

Mogford, E., \& Lyons, C. J. (2019). The impacts of international service learning on a host community in Kenya: Host student perspectives related to global citizenship and relative deprivation. Frontiers: The Interdisciplinary Journal of Study Abroad, 31(2), 86-104. https://doi.org/10.36366/frontiers.v31i2.456

Morrow, S. L. (2005). Quality and trustworthiness in qualitative research in counseling psychology. Journal of Counseling Psychology, 52(2), 250-260. https://doi.org/10.1037/0022-0167.52.2.250

Myers-Lipton, S. J. (1998). Effect of a comprehensive service-learning program on college students' civic responsibility. Teaching Sociology, 26(4), 243-259. 
Ollerenshaw, J. A., \& Creswell, J. W. (2002). Narrative research: A comparison of two restorying data analysis approaches. Qualitative Inquiry, 8(3), 329-347. https://doi.org/10.1177/10778004008003008

Onwuegbuzie, A. J., Dickinson, W. B., Leech, N. L., \& Zoran, A. G. (2009). A qualitative framework for collecting and analyzing data in focus group research. International Journal of Qualitative Methods, 8(3), 1-21. https://doi.org/10.1177/160940690900800301

Prins, E., \& Webster, N. (2010). Student identities and the tourist gaze in international service-learning: A university project in Belize. Journal of Higher Education Outreach and Engagement, 14(1), 5-32. https://openjournals.libs.uga.edu/jheoe/article/view/1174

Reilly, D., \& Senders, S. (2009). Becoming the change we want to see: Critical study abroad for a tumultuous world. Frontiers: The Interdisciplinary Journal of Study Abroad, 18(1), 241-267. https://frontiersjournal.org/index.php/Frontiers/article/view/265

Riessman, C. K. (2008). Narrative methods for the human sciences. SAGE.

Saldaña, J. (2013). The coding manual for qualitative researchers (2nd ed.). SAGE.

Saltmarsh, J., Hartley, M., \& Clayton, P. H. (2009). Democratic engagement white paper. Boston, MA: New England Resource Center for Higher Education.

Santiago-Ortiz, A. (2019). From critical to decolonizing service-learning: Limits and possibilities of social justice-based approaches to community service-learning. Michigan Journal of Community Service Learning, 25(1), 43-54. http://doi.org/10.3998/mjcsloa.3239521.0025.104

Schaffer, M., Hargate, C., \& Marong, K. (2015). Engaging communities in nursing education. International Journal of Research on Service-Learning and Community Engagement, 3(1). https://journals.sfu.ca/iarslce/index.php/journal/article/view/112

Schroeder, K., Wood, C., Galiardi, S., \& Koehn, J. (2009). First, do no harm: Ideas for mitigating negative community impacts of short-term study abroad. Journal of Geography, 108(3), 141-147. https://doi.org/10.1080/00221340903120866

Shallenberger, D. (2015). Learning from our mistakes: International educators reflect. Frontiers: The Interdisciplinary Journal of Study Abroad, 26, 248-263. https://doi.org/10.36366/frontiers.v26i1.369

Sharpe, E. K., \& Dear, S. (2013). Points of discomfort: Reflections on power and partnerships in international service-learning. Michigan Journal of Community Service Learning, 19(2), 49-57. http://hdl.handle.net/2027/spo.3239521.0019.204

Stanlick, S., \& Sell, M. (2017). Beyond superheroes and sidekicks: Empowerment, efficacy, and education in community partnerships. Michigan Journal of Community Service Learning, 23(1), 8084. http://doi.org/10.3998/mjcsloa.3239521.0023.107

Thomas, L., \& Chandrasekera, U. (2013). Uncovering what lies beneath: An examination of power, privilege, and racialization in international social work. In R. Tiessen \& R. Huish (Eds.), Globetrotting or global citizenship? Perils and potential of international experiential learning (pp. 90-111). University of Toronto Press.

Tiessen, R. (2013). Career aspirations and experiential learning abroad: Perspectives from Canadian youth on short-term placements. In R. Tiessen \& R. Huish (Eds.), Globetrotting or global citizenship? Perils and potential of international experiential learning (pp. 71-89). University of Toronto Press.

Tiessen, R., \& Huish, R. (2013). International experiential learning and global citizenship. In R. Tiessen $\&$ R. Huish (Eds.), Globetrotting or global citizenship? Perils and potential of international experiential learning (pp. 3-20). University of Toronto Press.

Tonkin, H., \& Quiroga, D. (2004) A qualitative approach to the assessment of international servicelearning. Frontiers: The Interdisciplinary Journal of Study Abroad, 10(1), 131-149. https://doi.org/10.36366/frontiers.v10i1.138

Tryon, E., Stoecker, R., Martin, A., Seblonka, K., Hilgendorf, A., \& Nellis, M. (2008). The challenge of short-term service-learning. Michigan Journal of Community Service Learning, 14(2), 16-26. http://hdl.handle.net/2027/spo.3239521.0014.202 
van Rensburg, E. J. (2014). Enablement - a foundation for community engagement through service learning in higher education. In M. Erasmus \& R. Albertyn (Eds.), Knowledge as enablement: Engagement between higher education and the third sector (pp. 41-61). Sun Press.

Warchal, J., \& Ruiz, A. (2004). The long term effects of undergraduate service-learning programs on postgraduate employment choices, community engagement and civic leadership. In M. Welch \& S. Billig (Eds.), New perspectives in service-learning: Research to advance the field (pp. 87-06). Information Age Publishing.

Warren, J. L. (2012). Does service-learning increase student learning? A meta-analysis. Michigan Journal of Community Service Learning, 18(2), 56-61. http://hdl.handle.net/2027/spo.3239521.0018.205

Whitney, B., Muse, S., Harrison, B., Edwards, K. E., \& Clayton, P. H. (2016). Learning from and with community organizations to navigate the tensions of democratic engagement. Michigan Journal of Community Service Learning, 23(1), 85-90. http://doi.org/10.3998/mjcsloa.3239521.0023.108

Zemach-Bersin, T. (2007). Global citizenship and study abroad: It's all about U.S. Critical Literacy: Theories and Practices, 1(2), 16-28.

http://www.criticalliteracyjournal.org/cljournalissue2volume1.pdf

\author{
About the Author \\ Jeremy R. Doughty is a resident director in the England Programs at the University Studies Abroad \\ Consortium. \\ Correspondence concerning this article should be addressed to Jeremy R. Doughty at \\ jeremy.doughty@usac.edu.
}

